\title{
The Effect of Earnings Management on Corporate Debt Policy
}

\author{
Jaisik Gong1)
}

\begin{abstract}
This paper examines the causal relationship between Korean firms' earnings management and their financing policies. Jensen (1986) and Harvey (2004) propose the agency theory model that firms may increase their debt levels, i.e., leverage ratios, in order to reduce agency costs between inside CEOs and outside shareholders. Agency costs are effectively mitigated because increased debt service reduces free cash flow available for managers to engage in self-interest activities. Thereafter, we hypothesize that firms with higher earnings management activities increase leverage levels to reduce their higher agency costs. We show that the higher earnings management, the higher agency costs. In this paper, we find that earnings management by Korean listed firms is positively associated with their higher leverage ratios and higher debt levels. This result is strongly consistent with our hypothesis that firms with higher earnings management activities are opted to choose their financing policies, increasing their leverage ratios, leading to the mitigation of their agency costs.
\end{abstract}

Keywords: Earnings Management, Financing Policy, Agency Theory, Debt Ratio, Earnings Quality

\section{Introduction}

This study empirically examines the relationship between a firm's earnings management and corporate financing policy. We test the hypothesis that the earnings management behavior conducted by corporate managers influences corporate debt policy, that is, leverage ratio. Statistical analysis is conducted on whether companies with extensive earnings management have significantly higher leverage ratios. Our paper differs from prior related studies in that we consider how earnings management influences corporate debt policy.

Corporate capital structure policy decisions are one of the most controversial issues in financial theory. The trade-off theory of capital structure is that the trade-off or balance between the benefits and costs of debt decides the optimal financial leverage ratio of a company. First, in terms of the benefits of debt, companies can increase leverage ratios to decrease agency costs between managers and shareholders. Leuz, Nanda and Wysocki[1] say that managers or insiders of a firm can pursue their own private interests and they often

Received(March 22, 2020), Review Result(1st: April 20, 2020, 2nd: June 08, 2020), Accepted(June 25, 2020)

1) (Professor) 38911 Dept. Finance \& Insurance, Daegu Univ., Jinryang, Kyungsan, Kyungbook, Korea email: bkgong@daegu.ac.kr 


\section{The Effect of Earnings Management on Corporate Debt Policy}

conduct earnings management that hides their unfavorable company performance from external investors[2]. Bharath, T. Sunder, J. Sunder and Shyam[3] argue that creditors making loan decisions or setting loan interest rates based on the reported profits of a company may have been misled by earnings management.

In this study, we use earnings management as a proxy conflict variable between corporate managers and outside investors, or as a proxy variable for agency costs. Earnings management has been employed as a proxy measure of earnings quality or information quality in existing literature. For example, Giannetti[4] says that the opaque disclosure policy of a company is used to enable the private control of insiders, so that earnings management can be regarded as an influence of the information quality and usefulness of a firm's financial statements.

Bhattacharya, Daouk and Welker[5] and Lang, Lins and Maffett[6] used earnings management variables to measure the degree of information asymmetry, since external investors have limited access to the company's information compared with insiders. Likewise, Francis, LaFond, Olsson and Schipper[7] and $\mathrm{Ng}[8]$ used earnings management as a substitute variable for the quality of information or the degree of profit quality. They state that through discretionary earnings management, corporate insiders can manipulate a firm's profit level in order to hide the true economic performance of a company from outside investors[9].

Earnings management can lead to a greater agency conflict or agency cost between managers and external investors. This enables managers to use information about a company's cash flow that is available only privately to its insiders[10]. In this case, Jensen[11] says that if the manager is actively engaged in earnings management using an accounting reporting method that is deliberately misleading, external investors' judgment on the cash flow of the company may be misinformed. Harvey, Lins and Roper[12] report that corporate leverage is likely to reduce agency costs in the firm.

Therefore, this study conducts an empirical study of whether financial leverage or corporate debt growth is impacted by earnings management, based on the agency cost theory for free cash flow. In other words, the information asymmetry of the cash flow of the company can be exacerbated as a firm's managers engage in discretionary earnings management. We can establish the hypothesis that the companies with high earnings management tend to increase their debt levels with a corresponding mitigation of their agency cost. With more active earnings management, the company's eligibility for debt can be expected to increase with a corresponding efficient operation of the control mechanism for mitigating agency costs.

In terms of debt costs, we can assess bankruptcy costs or financial difficulties in terms of financial trade-off theory. Haw, $\mathrm{Hu}$, Hwang and $\mathrm{Wu}[13]$ argues that companies with high 
earnings management tend to maintain a high debt ratio because earnings management side-steps accounting constraints in debt contracts and facilitates debt renegotiation during financial difficulties[14]. When earnings management produces a favorable performance return, credit rating agencies evaluate the credit rating and a default risk on the assumption that the financial statements of the company are rational and accurate. This makes it for firms to increase their debts. Therefore, it can be expected that the extent of earnings management and the ratio of financial leverage will have a positive correlation.

Therefore, the testable hypothesis of this study is stated as follows. Our test model employs debt ratio as a dependent proxy variable for corporate debt policy, and discretionary accruals as an independent proxy variable for a firm's earnings management.

$\mathrm{H}$ : Companies with aggressive earnings management are expected to have a high ratio of financial leverage.

This study is composed as follows: Chapter 2 explains the analysis data and statistical methodology of this study. Chapter 3 empirically examines the relationship between the level of debt and earnings management, that is, how the ratio of financial leverage increases significantly in companies that conduct earnings management. Chapter 4 summarizes the conclusions and implications of this study.

\section{Research Data and Test Model}

This study is based on the sample period from 2002 to 2017. It uses sample firms that were listed on the Korean securities market during the sample period. Their financial data were used for our statistical analysis.

It employs the Jones[15] model and Dechow, Sloan and Sweeney[16] model to measure discretionary accruals, the key independent variable of earnings management. The total accruals are deducted from the net profit before the special profit deduction that is collected from the financial statements of the company. Since the total accruals are affected by the sales increase and the mechanical equipment, the prediction and residual values of the regression model estimation are separated into non-discretionary accruals and discretionary accruals when the following regression model is estimated.

$$
\frac{T A C C_{i, t}}{T A_{i, t-1}}=\beta_{0 i} \frac{1}{T A_{i, t-1}}+\beta_{1 i} \frac{\triangle R E V_{i, t}}{T A_{i, t-1}}+\beta_{2 i} \frac{P P E_{i, t}}{T A_{i, t-1}}+\epsilon_{i, t}
$$




\section{The Effect of Earnings Management an Corporate Debt Policy}

Discretionary accruals obtained by the estimation of the above regression equation represent the earnings management that managers can manipulate when showing the profits of the company. According to Leuz, Nanda and Wysocki[1] and $\mathrm{An}, \mathrm{Li}$ and $\mathrm{Yu}[17]$, earnings management can be used as a substitute for agency costs between managers and outside investors. We can set that up as a hypothesis that companies that are considered to have high agency costs due to their aggressive earnings management are likely to raise their leverage ratios, resulting in reduced agency costs.

Therefore, the key testable research model of this study is a regression analysis of how discretionary accruals have a significant effect on corporate debt policy. The dependent variable of this regression analysis model is debt ratio Debt which is a reflection of corporate financing policy. The key independent variable of the regression model is the estimated AAC (the absolute value of discretionary accruals, an earnings management variable) obtained from the above estimation formula. Other control variables of the regression model are followed by total asset return ROA, market price-book value $\mathrm{MKBK}, \log$ value size of total asset value Size, and standard deviation of cash flow CFDStd as a risk indicator. Finally, statistical test is conducted on the below regression analysis model.

$$
\operatorname{Debt}_{i, t}=\alpha_{0 i}+\alpha_{1 i} A A C_{i, t}+\alpha_{2 i} R O A_{i, t}+\alpha_{3 i} M K B K_{i, t}+\alpha_{4 i} \text { Size }_{i, t}+\alpha_{5 i} \text { CFDStd }_{i, t}+v_{i, t}
$$

Finally, this study performs a statistical test of whether AAC as a substitute for earnings management has a significant correlation with corporate leverage ratio Debt, by empirically testing the above regression model.

\section{Test Results}

This chapter performs an OLS (ordinary least squares) regression analysis and a panel data regression analysis. Sample data is collected from companies that are traded on the Korean stock market from 2002 to 2017.

[Table 1] presents the average, standard deviation, minimum and maximum values for the variables included in the analysis model of this study. The mean of absolute value of discretionary accrual AAC, the main independent variable of this analysis model, is 0.1288 , and its standard deviation is 0.248 . The average debt ratio Debt, which is a dependent variable, is 122.05, and its standard deviation is 254.09. The control variables in this analysis model include the firm size variable Size, total asset return ROA, market price-book value ratio MKBK, and 
the standard deviation of cash flow CFDStd as a substitute variable for corporate risk. The averages of Size and ROA are 26.61 and 0.0269, respectively, and their standard deviations are 1.5 and 0.124 , respectively. The average of market value-book ratio (MKBK) is 16.76 and its standard deviation is 55.99 .

[Table 1] Basic Statistics

\begin{tabular}{|c|c|c|c|c|c|}
\hline Variable & $\mathrm{N}$ & Average & $\begin{array}{c}\text { Standard } \\
\text { Deviation }\end{array}$ & $\begin{array}{c}\text { Minimum } \\
\text { Value }\end{array}$ & $\begin{array}{c}\text { Maximum } \\
\text { Value }\end{array}$ \\
\hline \hline Debt & 7,931 & 122.05 & 254.09 & 0 & 8,887 \\
\hline AAC & 7,931 & 0.1288 & 0.248 & $4.97 \mathrm{E}-7$ & 7.46 \\
\hline Size & 7,918 & 26.611 & 1.500 & 22.61 & 32.92 \\
\hline ROA & 7,918 & 0.0269 & 0.124 & -3.47 & 3.36 \\
\hline MKBK & 7,397 & 16.767 & 55.990 & 0.150 & 1,740 \\
\hline CFDStd & 7,931 & $10,269.6$ & $84,851.9$ & 0 & $1,738,928$ \\
\hline
\end{tabular}

*Note: Debt is the debt ratio or leverage ratio. AAC is the absolute value of discretionary accrual, an earnings management variable. Size is a company size variable, the log value of the total assets. ROA is the total asset return, MKBK is the book-to-market value ratio of common stock, and CFDStd is the standard deviation of cash flow.

[Table 2] shows the result of an OLS analysis. The effect of the managers' earnings management on corporate debt policy is analyzed. According to the agency cost hypothesis based on the free cash flow, the larger the company's earnings management, the more information asymmetry between managers and investors about cash flow is, so it claims to increase its debt leverage to reduce agency costs. Haw, $\mathrm{Hu}$, Hwang and $\mathrm{Wu}[10]$ assert that if companies issue inflated profit reports, it will be easy for them to raise debts. Credit rating agencies or capital markets will assess the bankruptcy risk of those companies or their default risks as low. In [Table 2], the coefficient estimate for leverage ratio Debt in relation to discretionary accrual absolute value $\mathrm{AAC}$, which is an alternative to agency cost, is 0.609 and its standard error is 0.112 , showing a high positive value of significance.

This is the strong result supporting our hypothesis that companies that are considered to have high agency costs due to the aggressive earnings management adapt their financing policy to increase leverage ratio, leading to the reduction in agency costs. In addition, it shows that companies are actively manipulating their reported earnings in order to lower investors' default risk assessment in the capital market. This increases their corporate capital procurement by improving company credit ratings by credit rating agencies.

As for control variables, the coefficient estimates of ROA1 and MKBK, the profitability 


\section{The Effect of Earnings Management an Corporate Debt Policy}

indicators of the firm, are -207.61 and -0.509 , which are negatively significant. These show that the higher the profit performance, the lower the debt ratio. The coefficient estimation of the firm size variable Size1 is 0.330 , which shows a very positive significance. The larger the company size, the higher the firm debt level.

[Table 2] Effect of Earnings Management on Debt Policy: OLS Analysis - Dependent Variable: Debt (debt ratio)

\begin{tabular}{|c|c|c|c|c|c|}
\hline Variable & DF & $\begin{array}{c}\text { Coefficient } \\
\text { Estimates }\end{array}$ & Standard Error & $\mathrm{t}$-Val & Pr> ItI \\
\hline \hline Intercept & 1 & -6.703 & 0.48 & -13.89 & $<.0001$ \\
\hline AAC & 1 & 0.609 & 0.112 & $5.41^{* *}$ & $<.0001$ \\
\hline Size1 & 1 & 0.330 & 0.018 & $17.81^{* *}$ & $<.0001$ \\
\hline ROA1 & 1 & -207.61 & 22.26 & $-9.33^{* *}$ & $<.0001$ \\
\hline MKBK & 1 & -0.509 & 0.022 & $-22.46^{* *}$ & $<.0001$ \\
\hline CFDStd & 1 & $2.89 \mathrm{E}-7$ & $2.99 \mathrm{E}-7$ & 0.97 & 0.333 \\
\hline
\end{tabular}

*Note: Debt is the debt ratio or leverage ratio. AAC is the absolute value of discretionary accrual, an earnings management variable. Size1 is a company size variable, the log value of the total assets in the previous year. ROA1 is the total asset return in the previous year, MKBK is the book-to-market value ratio of common stock, and CFDStd is the standard deviation of cash flow.

[Table 3] shows the result of a Panel model analysis, which was conducted to enhance the robustness of our statistical analysis. Panel model analysis considers the time series cross-sectional characteristics of this study data. The results of [Table 3] are also very similar to the results of [Table 2]. In the Panel analysis of [Table 3], the coefficient estimate of discretionary accrual absolute value AAC, which is the main independent variable and also the proxy variable of agency cost, is 0.474 and its standard error is 0.11 . The results showing the estimates of very high significance for this alternative variable of earnings management confirm that the main hypothesis of this study is empirically supported. Thus, the larger the size of earnings management, the higher leverage ratio policy is maintained to increase the firm's debt level.

[Table 3] Effect of Earnings Management on Debt Policy: PANEL Analysis - Dependent Variable: Debt (debt ratio)

\begin{tabular}{|c|c|c|c|c|c|}
\hline Variable & DF & $\begin{array}{c}\text { Coefficient } \\
\text { Estimates }\end{array}$ & Standard Error & t-Val & Pr> ItI \\
\hline \hline Intercept & 1 & -5.129 & 0.76 & -6.73 & $<.0001$ \\
\hline
\end{tabular}




\begin{tabular}{|c|c|c|c|c|c|}
\hline AAC & 1 & 0.474 & 0.11 & $4.18^{* *}$ & $<.0001$ \\
\hline Size1 & 1 & 0.273 & 0.028 & $9.45^{* *}$ & $<.0001$ \\
\hline ROA1 & 1 & -152.27 & 21.57 & $-7.06^{* *}$ & $<.0001$ \\
\hline MKBK & 1 & -0.550 & 0.033 & $-16.43^{* *}$ & $<.0001$ \\
\hline CFDStd & 1 & $3.98 \mathrm{E}-7$ & 0 & - & - \\
\hline
\end{tabular}

*Note: Debt is the debt ratio or leverage ratio. AAC is the absolute value of discretionary accrual, an earnings management variable. Size1 is a company size variable, the log value of the total assets in the previous year. ROA1 is the total asset return in the previous year, MKBK is the book-to-market value ratio of common stock, and CFDStd is the standard deviation of cash flow.

The estimated results of the control variables including Size1, total asset return ROA1, market price-book value ratio MKBK and standard deviation CFDStd of cash flow are very similar to the estimated results of [Table 2].

In summary, the analyses of [Table 2] and [Table 3] showed that high leverage ratios were found in companies that have low earnings quality or high information asymmetry due to extensive earnings management. High leverage ratios were found to be associated with extensive earnings management.

\section{Conclusion}

In this study, we performed an OLS model analysis and a Panel model analysis of Korean companies that were traded from 2002 to 2017. Our research goal was to see how a company's earnings management behavior influences the firm's financing policy through the discretionary management of leverage ratios.

The hypothesis which we verified in this study was the agency cost hypothesis. It is argued that companies with extensive earnings management tend to select financing policies that increase leverage ratios to reduce agency costs because the degree of information asymmetry between managers and investors is severe.

The results of this study report that the coefficient estimation of the absolute value AAC, a discretionary accrual, which is a substitute for agency costs, shows a very high positive significance in both OLS and Panel model analyses. This empirically certifies the hypothesis that companies that engage in a lot of earnings management maintain corporate financing policies that keep their debt leverage ratios high. This study also provides interesting results that profitable and small firms show lower debt ratios.

This also suggests that companies may actively manage their earnings and inflate their reported profits, in order to reduce the risk assessment in the capital market as a part of their 
financing policy program for easy capital procurement. This study is summarized as the analysis of the effects of earnings management on corporate financial policy. With further studies, we need to encourage enhanced transparency of financial statements of Korean companies. In collaboration with policymakers, we should also strive to strengthen monitoring functions of Korean capital market.

\section{Acknowledgements}

This research was supported by the Daegu University Research Grant, 2019.

\section{References}

[1] C. Leuz, D. Nanda, P. Wysocki, Earnings management and investor protection: An international comparison, Journal of Financial Economics, (2003), Vol.69, No.3, pp.505-527.

[2] Moonjung Kim, Eunhee Kim, A study on perceived performance risk and product attitude in accordance with price discount and product types of Korea and Thailand consumers, International Journal of IT-based Management for Smart Business, (2016), Vol.3, No.1, pp.31-38.

[3] S. Bharath, T. Sunder, J. Sunder, V. Shyam, Accounting quality and debt contracting, The Accounting Review, (2008), Vol.83, No.1, pp.1-28.

[4] M. Giannetti, Do better institutions mitigate agency problems? Evidence from corporate finance choices, Journal of Finance Accountingand Quantitative Analysis, (2003), Vol.38, No.1, pp.185-212.

[5] U. Bhattacharya, H. Daouk, M. Welker, The world price of earnings opacity, The Accounting Review, (2003), Vol.78, No.3, pp.641-678.

[6] M. Lang, K. Lins, M. Maffett, Transparency, liquidity, and valuation; international evidence on when transparency matters most, Journal of Accounting Research, (2012), Vol.50, No.3, pp.729-774.

[7] J. Francis, R. LaFond, P. Olsson, K. Schipper, The market pricing of accruals quality, Journal of Accounting and Economics, (2005), Vol.39, No.2, pp.295-327.

[8] J. Ng, The effect of information quality on liquidity risk, Journal of Accounting and Economics, (2011), Vol.52, No.2, pp.126-143.

[9] Ju Huang, The effects of social capital on creativity and innovation performance, International Journal of IT-based Management for Smart Business, (2017), Vol.4. No.1, pp.13-18.

[10] Jeong-Ho Koo, Tae-Young Paik, Relationship between cost stickiness and agency problem, International Journal of IT-based Management for Smart Business, (2016), Vol.3, No.1, pp.15-20.

[11] M. Jensen, Agency costs of free cash flow, corporate finance, and takeovers, American Economic Review, (1986), Vol.76, No.2, pp.323-329. 
[12] C. Harvey, K. Lins, A. Roper, The effect of capital structure when expected agency costs are extreme, Journal of Financial Economics, (2004), Vol.74, No.1, pp.3-30.

[13] J. Haw, B. Hu, L. Hwang, W. Wu, Ultimate ownership, income management, and legal and extra-legal institutions, Journal of Accounting Research, (2004), Vol.42, No.2, pp.423-462.

[14] Junsik Choi, Gongcheol Jeong, Jaehwan Kim, An analysis of the management performance of real estate development company- focusing on real estate development company in Seoul, International Journal of IT-based Management for Smart Business, (2019), Vol.6, No.1, pp.7-12.

[15] J. Jones, Earnings management during import relief investigation, Journal of Accounting Research, (1991), Vol.29, No.2, pp.193-228.

[16] P. Dechow, R. Sloan, A. Sweeney, Detecting earnings management, The Accounting Review, (1995), Vol.70, No.2, pp.193-225.

[17] Z. An, D. Li, J. Yu, Earnings management, capital structure, and the role of institutional environ ments, Journal of Banking \& Finance, (2016), Vol.68, July, pp.131-152. DOI: https://doi.org/10.1016/j.jbankfin.2016.02.007 